\title{
STEEL FRAME VERSUS RACK SUPPORTED WAREHOUSE STRUCTURES
}

\author{
Rodoljub Vujanac, Miroslav Živković, Radovan Slavković, Snežana Vulović
}

Professional paper

Steel frame buildings based on vertical steel columns and horizontal beams or lattice are the most common style for industrial and distribution warehouses. Depending on the use, these typical warehouses are equipped with various types of free standing racks. Construction of self-supporting pallet racking warehouse, as a special form of pre-fabricated building, consists mainly of the racking system elements supporting the roof and walls, and also serves to storage materials. All elements are made of structural thin-walled steel profiles that provide the necessary lightness and low cost of construction. In this paper two systems of warehouse buildings are presented. Two structural designs are analysed and compared in terms of their construction process, technical feasibility with storage capacity, time advantage, economic viability and flexibility of usage.

Keywords: pallet racking; rack supported structure; steel frame structure; structure comparison; warehouse

\section{Čelične okvirne konstrukcije na suprot samonosivim regalnim skladištima}

Čelične okvirne konstrukcije hala sa stupovima i krovnim gredama ili rešetkama su najzastupljeniji stil građenja skladišnih hala za proizvodne i distributivne potrebe. Ovisno o namjeni, klasične skladišne hale su po potrebi opremljene različitim tipovima regalne konstrukcije. Konstrukcija samonosećeg paletnog regalnog skladišta, kao poseban vid montažnog objekta, uglavnom se sastoji od elemenata regalnog sustava koji nosi krov i zidove, a istovremeno služi i za skladištenje materijala. Svi elementi takve čelične konstrukcije su izrađeni od tankostjenih profila koji omogućuju potrebnu jednostavnost i nisku cijenu konstrukcije. U ovom radu su prezentirana dva sustava građenja skladišta. Provedena je usporedna analiza dva sustava s aspekta procesa izgradnje, tehničke izvedivosti i kapaciteta, vremena izgradnje, ekonomske isplativosti i fleksibilnosti u uporabi.

Ključne riječi: čelična okvirna konstrukcija; paletni regal; samonosiva regalna konstrukcija; skladište; usporedba struktura

\section{Introduction}

Steel frame warehouse structures are essential building types that serve the commercial purpose of storage of goods in achieving today's manufacturing and distribution needs determined by competitive markets. These buildings are usually large steel structures covering vast spans to provide the required capacity. Decision on the type of warehouse structure to construct depends on various reasons. Warehouse construction is a flourishing industry and thus requires sophisticated methods of construction to fulfil the requirement. Therefore, there is a need for both an individual and organization to analyse different structural designs available on the market, and identify which structure best fits their anticipated purpose. Since all the costs of doing business are on the rise, some of the aspects that an individual has to analyse when comparing different structures include the availability of space for construction, the cost of construction, storage capacity, height and the projected purpose of construction [1]. Mostly, handling of goods requires that goods are stored on pallets which are in turn placed on pallet racks as standard storage equipment. When choosing storage system, an engineer is faced with a wide array of options. The most common pallet rack configurations are conventional selective/adjustable pallet racks, doubledeep selective pallet racks, push-back, drive-in or drivethrough pallet racks, dynamic pallet racks and mobile rack systems [2]. Material handling equipment like stacker cranes and forklift trucks are used to transport goods to and from the pallets racks to the transportation vehicles or input/output zones. Conventional steel frame structures equipped with free standing rack configurations have been used to build warehouses, but with the advancement of technology, rack supported warehouses became very popular storage solution. In this paper two structural designs, both noticeable as pre-engineered buildings, will be analyzed and compared in terms of their technical feasibility, storage capacity, economic viability and flexibility of usage. These two structural systems will be explained briefly before proceeding with the comparison.

\section{Steel frame structures}

Single storey industrial buildings are typically used for industrial and distribution warehouses. To make the space suitable for warehousing as well as to achieve space utilization, the long span and high construction must be designed with the minimum number of internal columns. The traditional structural steel frame options for single storey industrial buildings are [3]:

- simple beam structure,

- portal frame structure and

- lattice structure.

Although having a simple design, simple beam structures shown in Fig. 1 a) can provide relatively short span up to $12 \mathrm{~m}$ with bracing needed for in-plane stability.

The most popular choice of structural form for single storey buildings with spans from 10 to $60 \mathrm{~m}$ is the portal frame because of its excellent structural efficiency and easy fabrication and erection, Fig. 1 b) and 1 c) $[3,4]$.

Multi-span frames can also be designed, using either single or multiple of internal columns, Fig. $1 \mathrm{c}$ ).

For longer spans over $60 \mathrm{~m}$ and/or heavy loads, structures with lattice structures as shown in Fig. 1 d) can be put to better use than portal frames with beams. However, fabrication of a lattice is generally more time consuming than for a beam, even though that modernization of fabrication equipment allows the optimization of fabrication times [3]. 


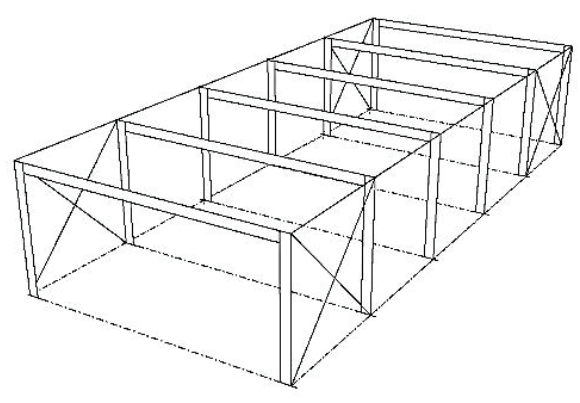

a) Simple beam structure

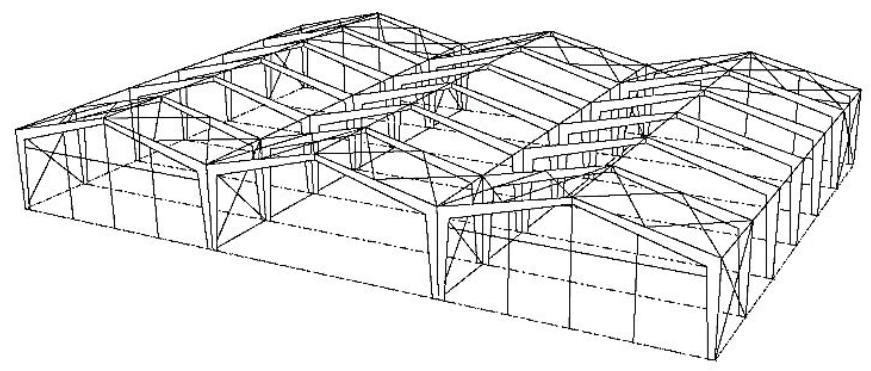

c) Multi-span portal frame structure

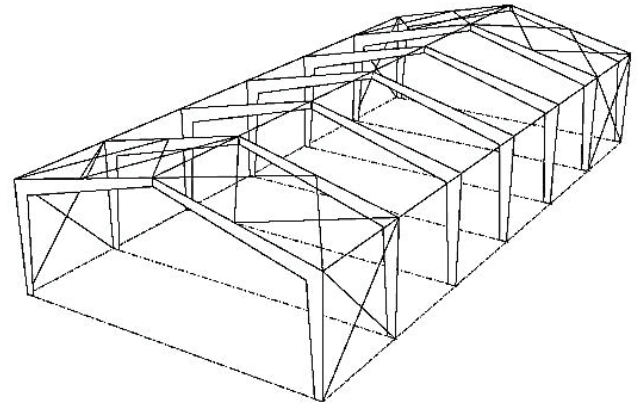

b) Single-span portal frame structure

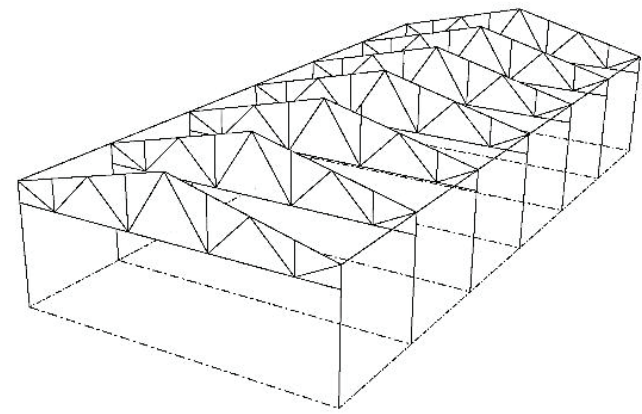

d) Lattice structure

Figure 1 Forms of frame building structures

Frames are placed uniformly at 6 to $10 \mathrm{~m}$ spacing along the building. Roof slopes can be between $5^{\circ}$ and $10^{\circ}$ ( $6^{\circ}$ is commonly adopted). The height of the portal frame is dependent on the functional use of the space. The clear height is likely to range from 5 to $12 \mathrm{~m}$ to allow for more efficient use of resources such as material handling equipment, different structural accessories like mezzanine floor, canopies in the original or future design as well as for free standing storage racks. Large doors for delivery can be placed in the end gables or between the side columns. The end gables are often designed also as portal frames to permit future expansion of the building to spread horizontally. The roofs and walls are attached to the frame and are supported by constructing the building in a rectangular grid.

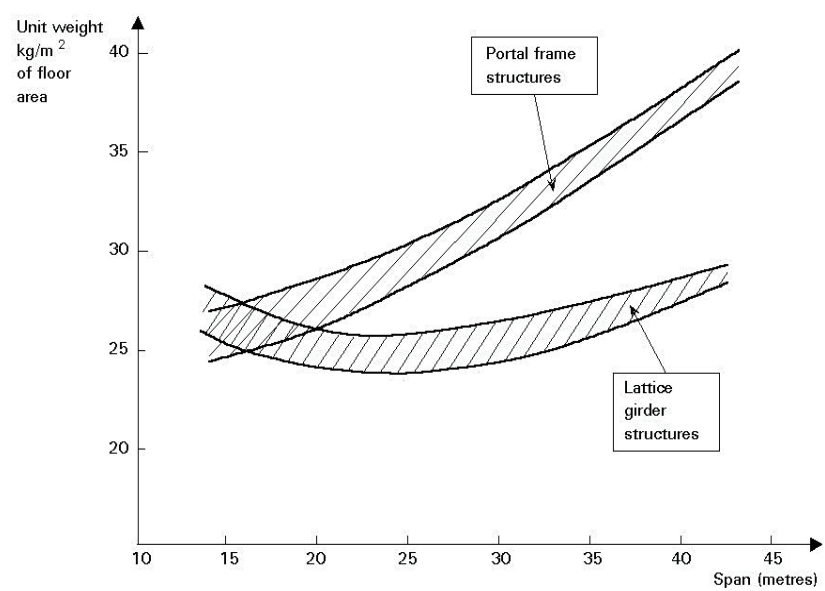

Figure 2 Comparison on frame weights for portal and lattice structures

Fig. 2 gives an indication of the relative material usage for the two most common steel frame building solutions, portal frame and lattice girder structures. Depending on the span of the building, the diagram clearly shows the optimum use of the appropriate type of construction in terms of material consumption and therefore all other costs.

The main components of the conventional steel frame buildings are shown in Fig. 3:

- Primary framing (columns and rafters).

- Secondary framing (purlins and side rails).

- Bracing system (longitudinal and roof bracing).

- Exterior cladding (roof and wall cladding).

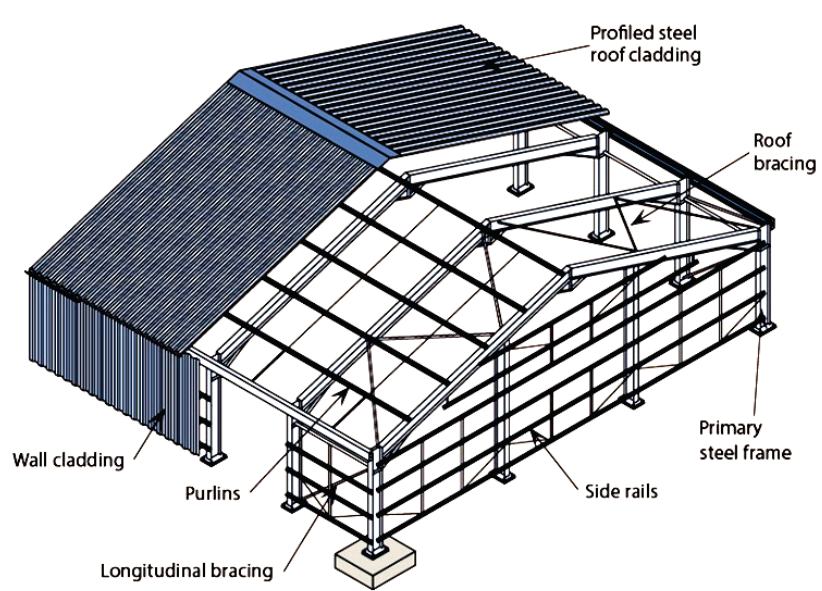

Figure 3 Main components of a steel frame building

For the primary framing systems in conventional steel frame building hot-rolled as well as cold-formed parts are extensively utilized $[5,6]$. The choice of cross-section is very wide, but experience has shown that a limited number of shapes are the most practical and economical. Members produced by hot-rolled "I" sections have constant cross section regardless of the varying magnitude of the local stresses along the member length. On the other hand usage of cold formed parts provides that main frames are tapered and then built up with adequate segments in depth at areas with highest stress. The sizes of every constituent member are chosen on the criteria of 
the maximum internal stress in the member. Because lattice girders have a much larger second moment of inertia and section modulus than a corresponding hotrolled "I" section of a similar weight, they have greater stiffness and resistance to load. Consequently, frame geometry matches the shape of an internal stress (bending moment) diagram, shown in Fig. 4, thus, optimizing the usage of materials and reducing the weight of the structure $[2,6]$.

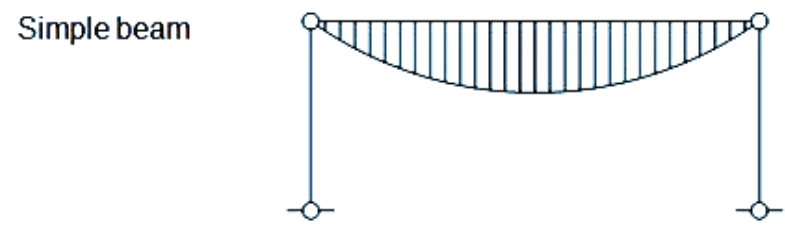

Portal frame

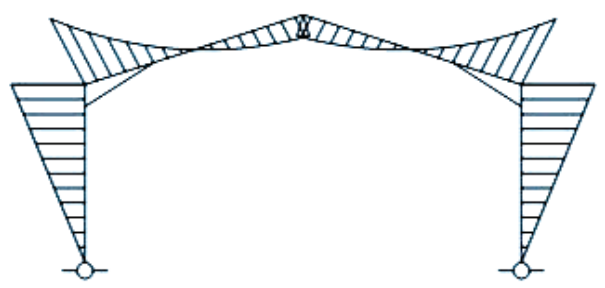

Truss

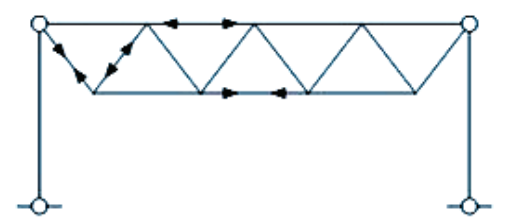

Figure 4 Bending moment diagram

The all above mentioned options may provide the main frame, but free standing pallet racks must be required separately to store the goods, Fig. 5.

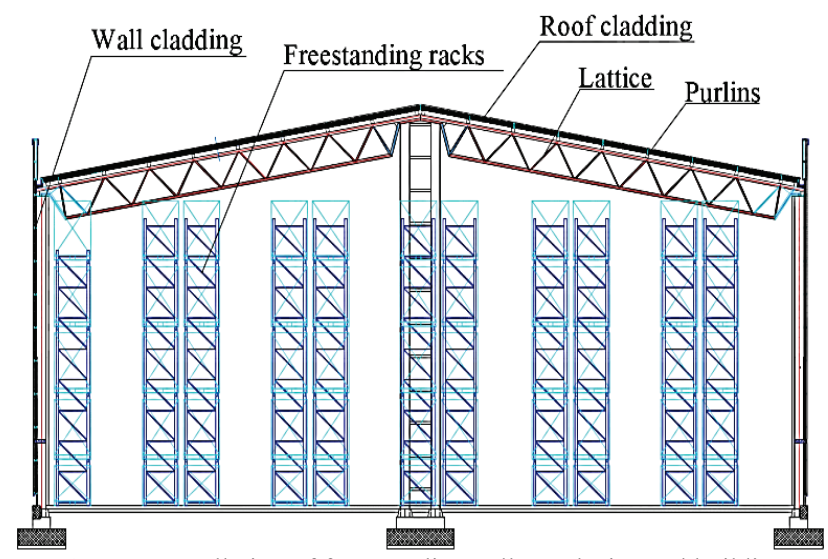

Figure 5 Installation of free standing pallet racks in steel building warehouse

In this style of structure, the cladding panels or trapezoidal sheets are normally supported by a system of light weight purlins and side rails. Cold formed " $\mathrm{Z}$ " or "C" sections are usually used for secondary structural members. The primary function of these secondary members is to transfer load from the cladding to the primary steel frame, including cladding self-weight, wind loads and, for roofs, imposed loads due to snow and maintenance access. The purlins and side rails may also be used to provide restraint to the rafters and columns and to transfer horizontal loads into the bracing system.
Bracing system consists of rods which are usually circular or rectangular in cross section. Sometimes it can be cold rolled or hot-rolled "L" profile.

\section{Rack supported structures}

Considering the potential cost savings in construction with the same effect of storage capacity, the idea is to reduce or eliminate heavy steel columns and beams or long span roof lattice in conventional frame buildings. The solution implies that aside from its primary warehousing function, the racking system acts as the basic structural support for the building's roof and walls $[7,8]$. As the racking system has uprights on much closer distance, additional savings surely come in the reduction in size of all supporting members, lighter rafter and purlin section.

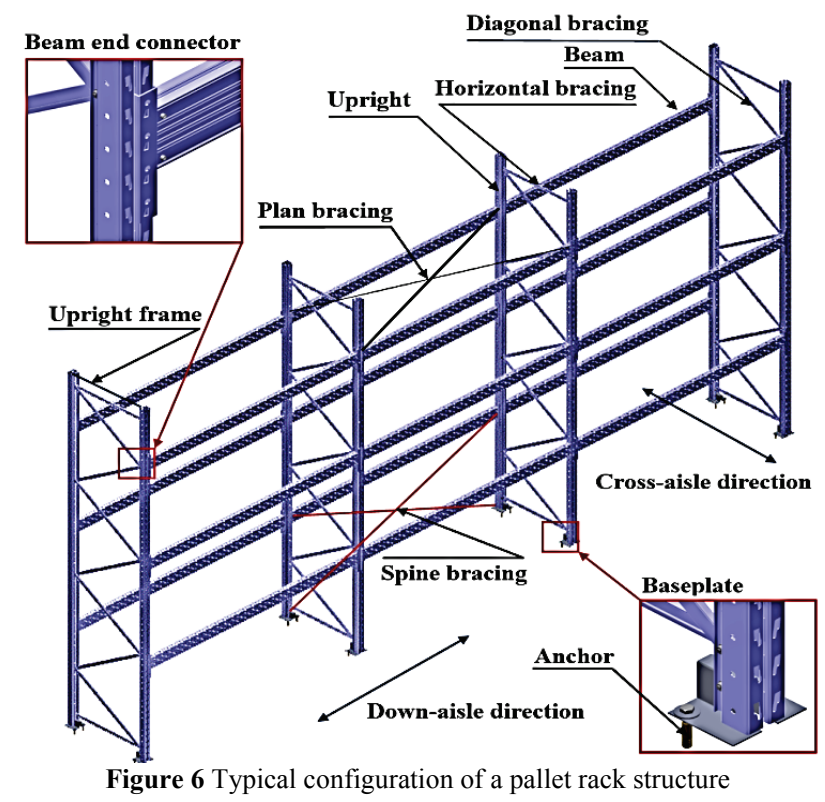

The main structural members of steel storage racking system are upright frames and horizontal beams as shown in Fig. 6 [9]. Upright frames lie in the vertical plane, in the cross aisle direction, normal to the main aisle of the rack. They consist of two uprights linked together by a system of bracing or batten members welded or bolted to the uprights. This bracing system provides rack stability in cross-aisle direction. Beams are horizontal members linking adjacent frames and lying in the horizontal direction parallel to the main aisle. Beam end connectors are welded to or otherwise formed as an integral part of the beams, which has hooks or other devices that engage in holes or slots in the upright. The down-aisle stability primary is attained by the stiffness of the semi-rigid joints between uprights and beams, and the semi-rigid stiffness of the base plate connection between upright and floor. The uprights are predominantly built from a thin-walled cold-formed perforated open section having one axis of symmetry. Beams are usually in the form of closed box sections built from thin-walled cold-formed steel. For high-rise rack structures when supporting particularly heavy loads, both uprights and beams may be built from hot-rolled steel or tubular section which may be hot-rolled or cold-formed. In this case upright and beam cross- 
section is usually doubly symmetric. Uprights do not contain perforations, except near connection points for the bolted connections in order to put the bolts, otherwise beams have welded connection to the uprights. Base plates are bolted or welded to the column and fixed to the floor by expanding type of anchor.

To avoid roof lattice structure, construction can be simplified so that the vertical columns of upright frames simply follow the slope of the roof and are interconnected in the cross direction with rafters, as shown in Fig. 7.

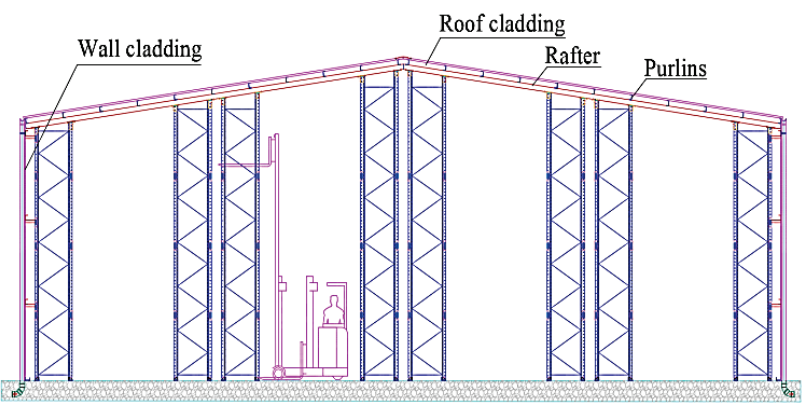

Figure 7 Cross section of rack supported warehouse with roof beams rafters

As another solution shown in Fig. 8, the roof structure is performed in the form of lattice [7]. There are many alternatives to design on the type of member to be used for the lattice structure:

a) Hollow sections - circular or rectangular.

b) Traditional sections - angles, tees, channels, I sections.

c) Combination of a) and b).

d) Cold formed open section of rack columns as shown in Fig. 8.

The selected lattice shown in Fig. 8 should reflect not only the design aim to produce the lightest structure but also ensure faster fabrication and erection requirements.

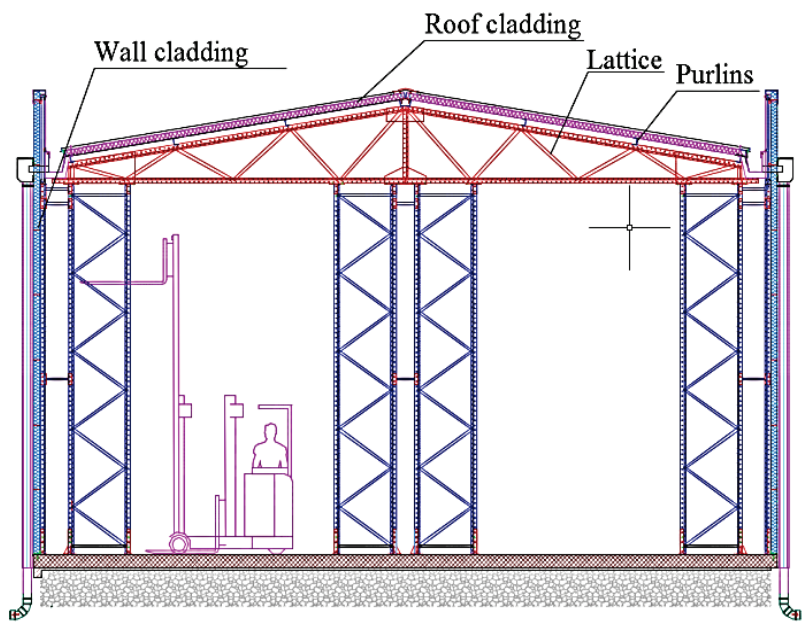

Figure 8 Cross section of rack supported warehouse with roof lattice

One specific solution to installation of roof structures is shown in Fig. 9 [8]. Connection of roof lattice with purlins preceded their connecting with standard horizontal rack beams. In this case beams allow connecting the two roof lattices on the ground and their easy lifting and installation on rack frames by crane. Purlins and side rails for rack supported structures are available in a variety of shapes and a wide range of sizes such as for the conventional steel frame building. Although the rack supported structures are much higher and self-sustaining, the environmental load calculated for their design such as wind or earthquake loading can be significant which is not usually taken into consideration for steel storage racks placed inside of another building.

This is why large rack supported structures must employ spine bracing acting together with plan bracing system in down aisle direction as shown in Fig. 6.

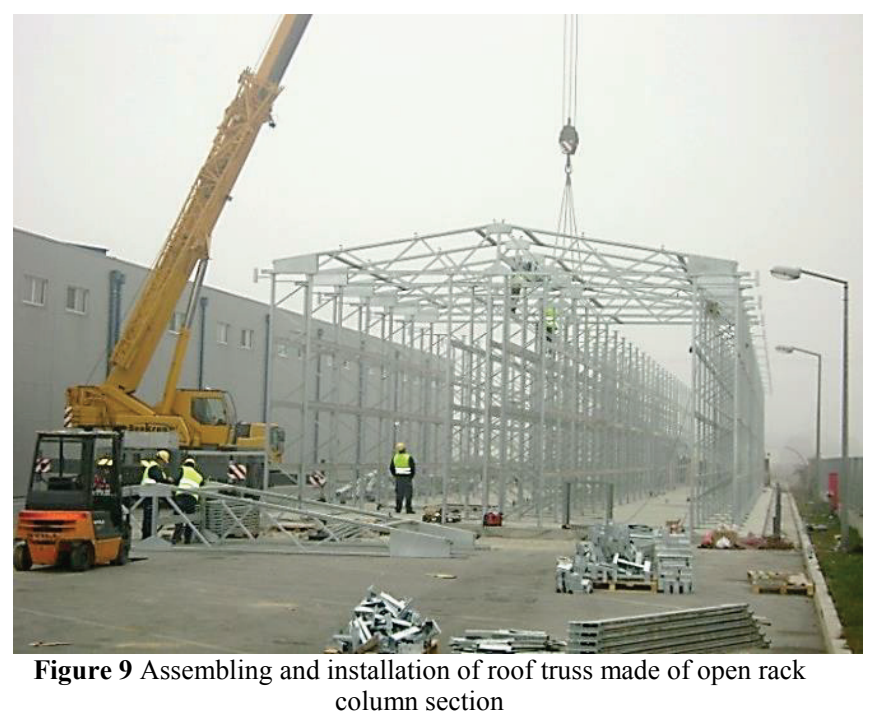

Lower rack supported buildings are usually operated by high forklift truck, as shown on configurations in Fig. 7 and 8 , or by stacker cranes for higher solutions [10]. When they are operated by stacker cranes, typically these systems are automatically controlled. This solution provides high storage density with minimum building footprint, low running costs, fast and accurate operations in man free environment. Aside from the conventional adjustable racking system, for palletized goods the drivein or cantilever system is also suitable for forming the main structure of a self-supporting warehouse.

\section{Comparative analysis}

Two structural designs will be analysed and compared in terms of their construction process, technical feasibility with storage capacity, time advantage, economic viability and flexibility of usage.

\subsection{Construction process}

The first step of the construction for a steel frame building is the pouring of foundation followed with the structural steel erection. The final bolt-up of the frames and bracing has to be done in the air which adds to the complications of the construction process. The roof and wall cladding are added afterwards. Once the building is closed and all the underground works finished, the floor is completed with a slab. The rack structures with material handling equipment, electrical and safety system, ventilation and some other utilities are erected after the slab has cured $[1,9]$. 
In the rack supported building, the slab is poured first, and the rack structures are erected next. In the low rise structures (less than $12 \mathrm{~m}$ ) rack installation starts directly from the ground level right on their position and is usually built by manpower [7, 8]. For the high rise structures, over $12 \mathrm{~m}$, spatial rack bays are assembled while lying on their sides at the ground level as shown in Fig. 9. The completely formed spatial modules are then positioned upright on the slab by crane. The installation of the rack, the material handling equipment and the cladding can be undertaken simultaneously. All the architectural elements such as doors, shutters, canopies, stairs, railings etc. can be aesthetically incorporated in both solutions. With no construction of columns and beams in the rack warehouse structure, huge savings can be realized in construction time and cost.

\subsection{Technical feasibility}

Warehouse building is not an "on the shelf" product, which can be designed as a standard product for all conditions, irrespective of its location. Every case is an individual case, as far as manufacturing and structural analysis is considered. Accurate engineering tolerances and clearances are maintained in production of components and installation of such buildings [9, 10]. Like everything else, properly designed and built, warehouse building whether be conventional or rack supporting, is able to withstand day-to-day stresses from the operation as well as external forces. When steel framed buildings are in question, the main structure is acting as an enclosure (primary force resisting system) for the free standing racks and has to protect these racks with goods from wind, rainfall and/or earthquake loads. On the contrary, rack supported structures have been designed to meet significant external environmental loads [10, 11]. These structures are suited for regions with high wind, snow load and seismic activity, as the forces will be distributed across the array of supporting uprights. Stability of the structure is ensured through several features such as connection between structural elements, anchorage system as well as bracing system in their down and cross-isle direction as shown in Fig. 6. The conventional steel framed structures may use bolted or welded connections which gives them a high resistance against the moment of forces thus reducing rotation as compared to the racking supported structures where the beam column joint uses semi-rigid boltless connectors to form moment resisting frames [12]. As demonstrated by Bernuzzi and Castiglioni [13] the welded and bolted connections will show a low rate of degradation of reloading stiffness under cyclic loading as compared to the rack supported structures. Under cyclic loading, these structures may suffer from high strength degradation.

The comparison Tab. 1 bellow compares the two structural systems when needed to storing approximately 2000 pallets.

In order to achieve effective space utilization, i.e. maximal storage capacity on the smaller space, conventional concept of having a building to house the selective storage racks requires the design of a roof structure capable of spanning the entire up to $27 \mathrm{~m}$ width as well as up to $12 \mathrm{~m}$ high columns to support the roof structure. Expansion of conventional steel frame structures in terms of width and height may prove costly. For example, as shown in table 1 storage density is very low with only $38 \%$ floor space used and $35 \%$ cubic space used. The alternative is to introduce external and/or interior higher columns to reduce the span of the roof structure which results in narrow aisle pallet racking system. While the first alternative is neither practical nor economical because of the unusually large span and height, the second alternative is not functional; especially the presence of interior columns does not only waste a certain percentage of the valuable storage volume, but also interferes with the racks as well as operation of material handling equipment. A comparison table will show a relatively small increase in storage capacity, just of $9 \%$ obtained when erecting a steel frame structure for more $5 \mathrm{~m}$ and reducing total area by $45 \%$. Specialised high forklift trucks up to $12 \mathrm{~m}$ operating in very narrow aisles provide high density floor utilisation of $46 \%$ and cube of $44 \%$.

Table 1 The comparison table of two conceptual designs

\begin{tabular}{|l|c|c|c|}
\hline \multicolumn{1}{|c|}{$\begin{array}{c}\text { Conceptual } \\
\text { designs }\end{array}$} & $\begin{array}{c}\text { Selective } \\
\text { pallet racking } \\
\text { in steel frame } \\
\text { building }\end{array}$ & $\begin{array}{c}\text { Narrow aisle } \\
\text { pallet racking } \\
\text { in steel frame } \\
\text { building }\end{array}$ & $\begin{array}{c}\text { Self } \\
\text { supported } \\
\text { automated } \\
\text { pallet racking }\end{array}$ \\
\hline $\begin{array}{l}\text { Storage } \\
\text { capacity (Pallet } \\
\text { positions) }\end{array}$ & 2000 & 2176 & 2080 \\
\hline Pallets in high & 5 & 8 & 16 \\
\hline $\begin{array}{l}\text { Floor space } \\
\text { (m) }\end{array}$ & $62,9 \times 27,0$ & $55,8 \times 17,0$ & $57,5 \times 8,9$ \\
\hline Total area (m $\left.{ }^{2}\right)$ & 1698 & 949 & 512 \\
\hline $\begin{array}{l}\text { Average floor } \\
\text { area / Pallet } \\
\text { positions }\end{array}$ & 0,85 & 0,44 & 0,25 \\
\hline $\begin{array}{l}\text { Storage } \\
\text { products area } \\
\text { (m } \times \text { m) }\end{array}$ & $53,9 \times 11,9$ & $45,80 \times 9,5$ & $46,3 \times 4,8$ \\
\hline Area (m $\left.{ }^{2}\right)$ & 641,4 & 435,4 & 222,4 \\
\hline Height (m) & 7,45 & 12,35 & 27,20 \\
\hline Volume (m $\left.{ }^{3}\right)$ & 4778,5 & 5377,0 & 6048,8 \\
\hline $\begin{array}{l}\% \text { Floor space } \\
\text { covered }\end{array}$ & $38 \%$ & $46 \%$ & $43 \%$ \\
\hline $\begin{array}{l}\text { Ceiling height } \\
(\mathrm{m})\end{array}$ & 8 & 13 & 28 \\
\hline $\begin{array}{l}\text { Building } \\
\text { volume (m }\end{array}$ & 13586 & 12338 & 14329 \\
\hline $\begin{array}{l}\text { Average } \\
\text { building } \\
\text { volume / Pallet } \\
\text { positions }\end{array}$ & 6,79 & 5,67 & 6,89 \\
\hline $\begin{array}{l}\% \text { Building } \\
\text { cube utilization }\end{array}$ & $35 \%$ & $44 \%$ & $42 \%$ \\
\hline $\begin{array}{l}\% \text { Pallets } \\
\text { immediate } \\
\text { accessible }\end{array}$ & $100 \%$ & $100 \%$ & $100 \%$ \\
\hline
\end{tabular}

The concept of rack supported buildings is then apparent. By placing the cladding of the building directly on the rack structure, the need of building columns and long roof lattice is eliminated. Space reduction by significant $70 \%$ with higher rack structures more than 20 $\mathrm{m}$ provide same storage capacity. Bearing in mind that height of rack supported structure is possible to extend 
over $40 \mathrm{~m}$, they are still limited by local standards and by the reach height of material handling equipment. In that case, they are mostly outfitted with automated storage and retrieval system (AS/RS) [10].

\subsection{Time advantage}

Both systems are designed, produced and installed by companies that have expertise in the erection of these prefabricated structures, so at the first stage design process is very quick and efficient and can last 20-30 working days. Both structures are mainly formed by standard elements and connection design, so time necessary to complete documentation, i.e. engineering and architectural time is significantly reduced. Due to computerizing in design, specialized software is used to optimize material required. Then the main differences stem from the period of manufacture and assembly. Even all the members are manufactured completely in the factory for both types of structures [6], production of standard light thin-walled rack elements is faster and easier due to their mostly automated serial production with duration of 30 working days. At the job site, members of conventional steel structures use bolted and welded connections, assembling lasts 30 working days. The erection process of rack supported structures is faster and much easier with fewer requirements for equipment, as the bulk of work is performed only by manpower due to semi rigid boltless connectors between the most common elements, rack columns and beams. Process of erection rack cladding and material handling equipment in 25 working days can take place simultaneously which means additional time reduction. Hence, rack supported structures require less overall time for realization sometimes up to $50 \%$ as compared to the steel framed structures of warehouse with similar storage capacity. It should be highlighted that a warehouse of 300,500 or $800 \mathrm{~m}^{2}$ can be built in approximately the same time, since pre-fabrication does not depend on its size, and larger area can be compensated with more assemblers and equipment during erection.

\subsection{Cost effectiveness}

The total price of the steel building warehouse equipped with free standing racks as well as rack supporting warehouse as shown in Fig. 10 consists of cost of engineering, foundation, raw material, fabrication, erections, installations, utilities and transport cost. In addition to understanding the different elements that make up the overall cost of both styles of constructions, it is important to know their relative proportions as well as interrelationship between them as shown in Fig. 10.

It is often assumed that a structure with minimum tonnage will also have the lowest cost. But, sometimes, complex designs, with higher proportions of non-standard elements or with higher fabrication or installation requirements can lead that overall rate per tonne is likely to be higher.

The following Tab. 2 describes the comparative costs analysis of the two concepts. This analysis based on an application that provides 1000 pallet picking positions in the warehouse space with dimensions length $50 \times$ width $16 \times$ height $7 \mathrm{~m}$ is shown in Figs. 8 and 9, [8].

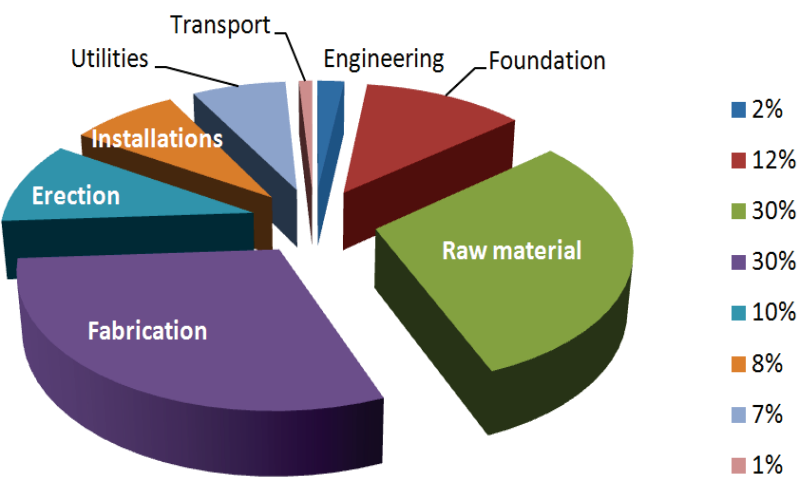

Figure 10 Distribution of costs for typical steel frame warehouse building with free standing racks as well as rack supported warehouse

Table 2 Breakdown of costs for typical steel frame warehouse building with free standing racks as well as rack supported warehouse

\begin{tabular}{|c|c|c|c|c|c|c|}
\hline \multirow[b]{2}{*}{ Cost } & \multirow[b]{2}{*}{$\stackrel{. \Xi}{\Xi}$} & \multirow[b]{2}{*}{ 䳂 } & \multicolumn{2}{|c|}{ Unit price $€$} & \multicolumn{2}{|c|}{$\begin{array}{c}\text { Total price } \\
\times 10^{3} €\end{array}$} \\
\hline & & & 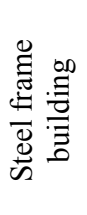 & 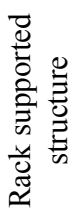 & 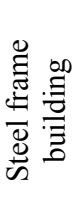 & 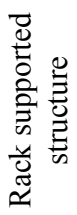 \\
\hline Project & $\mathrm{m}^{2}$ & 800 & 7,5 & 5 & 6 & 4 \\
\hline $\begin{array}{c}\text { Foundation } \\
\text { and slab }\end{array}$ & $\mathrm{m}^{2}$ & 800 & 45 & 30 & 36 & 24 \\
\hline Steel structure & $\mathrm{m}^{2}$ & 800 & 130 & 100 & 104 & 80 \\
\hline Erection & $\mathrm{m}^{2}$ & 800 & 15 & 10 & 12 & 8 \\
\hline Installations & $\mathrm{m}^{2}$ & 800 & 25 & 25 & 20 & 20 \\
\hline Utilities & $\mathrm{m}^{2}$ & 800 & 50 & 50 & 40 & 40 \\
\hline Transport & $\mathrm{m}^{2}$ & 800 & 8,75 & 5 & 7 & 4 \\
\hline \multicolumn{5}{|c|}{ Total price per solution $€$} & 225 & 180 \\
\hline
\end{tabular}

In terms of cost, rack supported warehouses provide higher density storage solution within lower overall cost due to the following facts:

- The entire project for rack supported buildings is mostly turnkey projects that are executed by one party. Multiple contractors may be involved for the conventional steel framed warehouses, where the structure and the racks are two different elements.

- As far as the rack structure is concerned, its columns are at a much closer distance which reduces the size of the supporting members as well as requires lighter foundation.

- Rack supported warehouse eliminates the need for building steel columns and long span roof trusses or beams which leads to the cheaper construction cost as well as transport cost due to less material.

- Due to possibility for simultaneous execution of multiple activities duration and therefore cost of erection is lower.

- The cost of installations and utilities is similar for the same purpose of both buildings.

- Less money is amounted for insurance by the rack supported structures due to their low cost.

But, steel frame structures undergo a smaller annual depreciation. This is because the walls and roof of the 
rack supported structures are deemed as equipment enclosures, which means that the cost of the structure can be depreciated at a course of less than 15 years while normally a time period of more than 20 years is considered for conventional buildings.

\subsection{Flexibility of usage}

In terms of flexibility of usage thus is a main advantage of conventional warehouse. The conventional steel frame buildings can combine the purpose of storage with other processes such as manufacturing, while rack supported warehouses are only serving the purpose of storage as its primary structure is based on pallet racks.

As evident from the method of construction, in both cases the expansion process is very easy as it only involves creation of additional steel frames as well as racks with accompanying components adjacent to the existing warehouse structure. In both cases the client can reuse the structure at any other location, as the structure can be easily disassembled, transported and assembled at another location.

\section{Conclusions}

Recognizable as pre-engineered buildings, steel frame as well as rack supported structures can be implemented for a variety of warehouse applications. Conventional steel frame structure is a versatile building system and can be finished to serve any other functions. With numerous advantages, rack supported warehouse can provide a valuable alternative to conventional steel frame warehouse. The primary difference arises in terms of the main supporting structure which leads to the primary benefits - space utilization. Technically speaking rack uprights acting as columns serve the dual purpose of storage and support for the building structure. To maximize the use of available and usually very expensive land, reduce labour costs, increase distribution efficiency and control and decrease energy use, the concept of rack supported warehouse becomes more economical warehousing solutions for storage above 12 meters in height. Rack supported warehouse is a cost effective solution as overall structure is lighter. Cost saving is also achieved through reduction of overall construction time (sometimes up to $50 \%$ ) due to automated production as well as erection of racks, cladding and material handling equipment which can be undertaken simultaneously. Additionally equipped with an automated storage and retrieval system, which uses a robotically guided crane together with in and out bound conveyors, the automated system can operate 24/7 with minimal human oversight. How much overall cost-effective it is, will depend upon all the factors mentioned above. Rack supported warehouses are particularly suited for high volume distribution centres, third party logistic operators and fast moving consumer goods companies where there is a need to optimise storage density. The most obvious drawback of rack supported structures is adaptability. Unlike a conventional steel frame warehouse with free standing racks which can be re-configured or put to alternative use, there is no second life for a rack supported warehouse. It can only be used for the purpose for which it was designed and installed.

\section{Acknowledgements}

The present work has been supported by the Ministry of Education, Science and Technological Development of the Republic of Serbia (Project No. TR32036).

\section{References}

[1] Vujanac, R.; Miloradovic, N.; Slavkovic, R. Criteria of effective layout designing of pallet racking. // Research and development of mechanical components and systems IRMES '06 / Banjaluka, 2006, pp. 65-70.

[2] Vujanac, R. Development of methodology for design and calculation of carrying elements of storage systems. // Master Thesis, Faculty of Mechanical Engineering University of Kragujevac / Kragujevac, 2007.

[3] Single storey industrial buildings, http:// www.steelconstruction.info/ (28.03.2013)

[4] Construction of Steel Warehouse Building, http:// www.reidsteel.com/warehouse-buildings.htm/ (28.03.2013)

[5] Satpute, R. S.; Varghese, V. Building Design Using Cold Formed Steel Section. // International Refereed Journal of Engineering and Science (IRJES). 1, 2(2012), pp. 01-16.

[6] Firoz, S.; Kumar, B. S. C.; Rao, S. K. Design Concept of Pre-engineered Building. // International Journal of Engineering Research and Applications (IJERA). 2, 2(2012), pp. 267-272.

[7] Vujanac, R.; Slavkovic. R.; Miloradovic, N. Warehouse Solution in The Phermaceutical Institution of Montenegro "Montefarm" Podgorica. // International Conference "Civil Engineering - Science and Practice" - GNP 2006 / Žabljak, Montenegro, 2006, pp. 953-958.

[8] Vujanac, R.; Maksimovic, D.; Slavkovic. R. Self-supported Warehouse Structure Completely Built of Racking Pallet Racking System. // 4th International Conference "Civil Engineering - Science and Practice" - GNP 2012 / Žabljak, Montenegro, 2012, pp. 899-904.

[9] FEM Document 10.2.02: The Design of Static Steel Pallet Racking, Section X of FEM, August, 2000.

[10] FEM Document 10.2.10. (9.831): Calculation Principles of Storage and Retrieval Machines, Tolerances, deformations and clearances in the high - bay warehouse, Section IX of FEM, February, 1995.

[11] FEM Document 10.2.08.: Recommendations for the Design of Static Steel Pallet Racking in Seismic Conditions, Working Group "APR Seismic design" of FEM (European Racking Federation), October, 2009.

[12] Baldassino, N.; Bernuzzi, C. Analysis and behaviour of steel storage pallet racks. // Thin-Walled Structures. 37, (2000), pp. 277-304. https://doi.org/10.1016/S0263-8231(00)00021-5

[13] Bernuzzi, C.; Castiglioni A. C. Experimental analysis on the cyclic behaviour of beam-to-column joints in steel storage pallet racks. // Thin-Walled Structures. 39, (2001), pp. 841-859.

https://doi.org/10.1016/S0263-8231(01)00034-9 


\section{Authors' addresses}

Rodoljub Vujanac, PhD, Assistant Professor

University of Kragujevac, Faculty of Engineering

Sestre Janjic 6, 34000 Kragujevac, Serbia

E-mail: vujanac@kg.ac.rs

Miroslav Zivković, PhD, Full Professor

University of Kragujevac, Faculty of Engineering

Sestre Janjic 6, 34000 Kragujevac, Serbia

E-mail: zile@kg.ac.rs

Radovan Slavković, PhD, Full Professor

University of Kragujevac, Faculty of Engineering

Sestre Janjic 6, 34000 Kragujevac, Serbia

E-mail: radovan@kg.ac.rs

Snežana Vulović, PhD, Researcher Associate

University of Kragujevac, Faculty of Engineering

Sestre Janjic 6, 34000 Kragujevac, Serbia

E-mail: vsneza@kg.ac.rs 